\title{
Transnational Women Writers in Europe: the Italian case-study ${ }^{1}$
}

\author{
Vita Fortunati* \\ University of Bologna
}

\begin{abstract}
My paper is divided in two parts: the first theoretical it is focused on the importance of Transnational Studies. Comparative Studies, Gender Studies and Translation Studies are in a transitory phase, a moment of great change implicit in a new perspective that wants to take into account a 'global' vision on the state of art in these three fields. The canonical division between literary/cultural studies and translation is not acceptable anymore, because translation is nowadays an hermeneutical category important to understand the complexity of the world. A research area that seems to unite this new notion of comparatism and translation is that of "Transnational literatures/cultures", where the term 'trans' outlines, not only the passage among cultures, literatures and languages, but also the overcoming of barriers and national borders. In the second part I analyse some Transnational Women Writers, who have chosen to write their fiction in Italian: Ornella Vorpsi (Albania), Lilia Bicec (Moldova), Geneviève Makaping (Cameroon), Christina de Caldes Brito (Brazil), Jarmila Ockayová (Slovakia) and finally, Jhumpa Lahiri (Bangladesh/USA). I analyse the reasons of their choice and the specificity of their contribution to Transnational Literatures/Cultures.
\end{abstract}

Keywords: Transnational Studies, Transnational Women Writers, Ornela Vorpsi (Albania), Lilia Bicec (Moldova), Geneviève Makaping (Cameroon), Christina de Caldes Brito (Brazil), Jarmila Ockayová (Slovakia), Jhumpa Lahiri (Bangladesh/USA).

Astratto: Il mio saggio é diviso in due parti: la prima teorica si incentra sull'importanza degli Studi Transnazionali. Gli Studi Comparati, gli Studi di Genere e quelli sulla Traduzione sono in una fase di transizione, in un momento di grande cambiamento che sottende una nuova prospettiva che mira a tenere presente una visione "globale" sullo stato dell'arte in questi tre settori di studio. La divisione canonica tra gli studi letterari/culturali e quelli della traduzione con è più accettabile, perché la traduzione oggi è diventata una categoria ermeneutica impor- 
tante per capire la complessità del mondo. Un'area di ricerca che sembra unire questa nuova nozione di comparatismo e di traduzione è quella delle "Culture e Letterature transnazionali”. Il termine "trans" sottolinea non solo il passaggio tra le culture, le letterature e le lingue, ma anche il superamento delle barriere e dei confini nazionali. Nella seconda parte analizzo le scrittrici transnazionali che hanno scelto di scrivere i loro romanzi nella lingua italiana. Igiaba Scego(Somalia), Ornela Vorpsi (Albania), Lilia Bicec (Moldavia), Geneviève Makaping (Cameron), Christina de Caldes Brito (Brasile), Jarmila Ockayová (Cecoslovacchia) and Jhumpa Lahiri (Bangladesh/USA). Indagherò inoltre le ragioni della loro scelta e la specificità del loro contributo all'interno delle Letterature e delle Culture transnazionali.

Parole chiave: studi transnazionali, scrittrici transnazionali, Ornela Vorpsi (Albania), Lilia Bicec (Moldova), Geneviève Makaping (Cameroon), Christina de Caldes Brito (Brazil), Jarmila Ockayová (Slovakia), Jhumpa Lahiri (Bangladesh/USA).

I- I would like to divide my paper in two parts: in the first theoretical I want to stress why according to my opinion Transnational Studies and Cosmopolitanism are important in our contemporary world, in the second part I analyse some transnational women writers who have chosen to write their fiction in Italian.'

Comparative Studies, Gender Studies and Translation Studies are in a transitory phase, a moment of great change implicit in a new perspective that wants to take into account a 'global' vision on the state of art in these three fields. The canonical division between literary/cultural studies and translation is not acceptable anymore, because translation is nowadays an hermeneutical category important to understand the complexity of the world. A research area that seems to unite this new notion of comparatism and translation is that of "Transnational literatures/cultures", where the term 'trans' outlines, not only the passage among cultures, literatures and languages, but also the overcoming of barriers and national borders. Sociologists have pointed out that the nation state category needs to be reconceptualized in the era of globalization. According to William Robinson (1998: 565), the "Nation State" must be seen as a "specific social relation inserted into larger structures that may take different, and historically determined, institutional forms." In her book The Sociology of Globalization the Dutch sociologist Saskia Sassen (2007), studies the ways global institutions, such as the World Trade Organization, intersect with the set of processes that occur on the national and local levels, in such a way that the $\mathrm{Na}$ tion State is modified. Sassen proposes an analysis through the theory of re-scaling: globalization crosses the various institutions established by the different "Nation 
States". The various hierarchies do not disappear, but they intersect thanks to the presence of "new scales", which condition and change the old institutions (Benvenuti/ Ceserani 2012: 70-74).

From this perspective the term 'transnational' recuperates the possibility of exchanges with extra-European countries underlining people's movements and writings about new configurations of geographical and cultural spaces. The transnational perspective permits to re-analyze the global cultural/literary scene not only from an economic or sociological perspective but also a literary and cultural one. In one of my recent articles I have argued that Transnational literature and a revised concept of Cosmopolitanism are strictly connected. ${ }^{2}$ Transnational Literature can help in acquiring a 'rooted cosmopolitanism' perspective against the contemporary rise of political nationalisms within the European and extra-European contexts. Cosmopolitanism in our contemporary time has become an important issue in order to accept the challenge of globalization and to contrast dangerous phenomena such as the crisis of democracies, racism and xenophobia, among others. Its strength consists in stressing essential universal values such as human dignity, freedom, religious tolerance, solidarity and the pursue of human happiness. Cosmopolitanism is not incompatible with local specificity (one's own roots) as suggested by the anthropologist Kwame Antony Appiah (1997) who stresses in his work the idea of "rooted cosmopolitanism" meaning that in the contemporary/globalized world everyone is a "rooted cosmopolitan". Cosmopolitanism values the variety of human forms of social and cultural life, contrasting any homogenized global culture.

The term "transnational" is difficult to define, because it does not just mean going beyond the concept of nation, but because it also implies a transit, a writer's passage from one language/culture to another, or, as happens in the contemporary world, characterised by continuous displacements, from one language/culture to several others. In this sense the term hyphenated-writer, which is closely linked to postcolonial processes and migrations, does not appear to be wholly appropriate to most of the European transnational writers. The definition "transnational literature", just like "world literature", is not fixed, but mobile, on the move, so to speak. For this reason, defining a female writer as "transnational" seems to be a complex operation. It implies keeping in mind a series of considerations: firstly, the biographical and existential reasons of each writer, and the intimately connected economic and political motivations of her exile. For a long time, the identity of a writer would pass through her choice of her so called "mother tongue": what we witness in transnational writers is an interesting phenomenon: their choice of writing novels in a different language from that of their homeland, i.e. that of their host country.

A central problem in transnational literatures written by women is that of identity, not considered as a monolithic entity but as fluid, an identity that overcome painful experiences, but that can be rebuilt through writing in a different language, 
not the mother tongue. The issue of the mother tongue is central in Azade Seyhan's book (Writing Outside the Nation, 2001), since a central problem in transnational literature written by women is identity, considered as a fluid entity that overcomes painful experiences and that can be rebuilt through writing in a language other than the mother tongue. National identity seems not to be founded on the mother tongue anymore:

If language is the single most important determinant of national identity, as many have argued, and narratives (specifically, epics and novels) institute and support national myths and shape national consciousness(e.p, the Finnish epic Kalevala), what happens when the domain of national language is occupied by non-native writers, writers whose native, mother, home, or community language is not the one they write in? (Seyhan 2001: 8)

For this reason, in many of their novels or essays, the reasons for this choice are elucidated, being as they are closely connected to a complex identifying process: the passage from one language/culture to another involves a distancing process allowing them not only to observe their surrounding reality from an outsider, marginal point of view, but also to operate a sort of self-translation. The writers become translators of an in-between identity.

The richness of the different linguistic and cultural background of transnational writers makes generalising their specific characteristics very difficult, because they are, to put it mildly, an extremely varied typology. In this paper we will discuss writers who have chosen Italy as their abode and Italian as their language of expression. This phenomenon may be defined with the term used by Francoise Lionnett and Shu-mei Shi, that is “minor transnationalism”, since Italian language and literature have been considered "minor" players on the European stage, compared to English and French language and literature: two nations who also played a greater role in the colonial phenomenon and who conversely where more culturally influenced by it.

In the Introduction to the volume Minor Transnationalism(2005) Francoise Lionnet and Shu-mei Shih underline the fact that in order to study what has been defined as "minor transnationalism" it is necessary to abandon a vertical perspective where a group was hierarchically placed in a higher position and to find a transversal perspective. We should not think about binary oppositions or centre versus periphery but we need to underline the relationships among minor transnationalisms. Today it is important to discuss the relationship among different 'margins', different ethnic communities.

There is a clear lack of proliferation of relational discourses among different minority groups, a legacy from the colonial ideology of divide and conquer that has historically pitted different ethnic groups against each other. The minor appears always mediated 
by the major in both its social and its psychic means of identification... The transnational... can be conceived as a space of exchange and participation wherever processes of hybridization occur and where it is still possible for cultures to be produced and performed without the necessary mediation by the centre". (Lionnet and Shih 2005: 2-8)

Studying these writers, one realises how little Italian colonialism has been studied, or even totally dismissed, together with its effects on our society: a hidden, repressed and hardly considered phenomenon. Now transnational writers, especially those originating from the Italian ex- colonies (especially Eritrea and Somalia) propose a serious reflection on Italian colonial history and are able to explain the prejudices and the sometime racist and xenophobe attitude towards different ethnicities and cultures. ${ }^{3}$

Another example to underline the complexity of defining a transnational writer arises from Eastern European or border country migration to Italy (for instance, from Moldavia or Albania). The latter reveal exactly how much the myth of a united Europe no longer corresponds to current reality, since the very definition of Europe is flexible and unstable. The contribution given by these writers and their richness is due not just to their showing us histories and cultures we have long ignored despite their geographical closeness, but also to their making us face a critical and ethical reflection of our own social reality. Moreover they have highlighted how important it is to imagine and construct a transnational encounter founded on an ethical relationship in the sense envisaged by Emmanuel Levinas(1969). They underline the importance of a dialogue that takes into consideration the history of colonization and imperialism and the political-social spaces where it takes place. Only in this way we can think about a transnational politics based on interaction, communication and representation. The importance on ethics on the behaviour we should assume towards "the other" can make women aware that one of the limits in this dialogue and exchange is to adopt monistic perspectival narrowness in scholarship (Stanford 20II: 24). Women propose a transversal and transpositional politics where to be ethical is able to shift position to those of "the other" and many others beyond the binary logic of Western hegemony and not Western one.

Our case studies consist of writers coming from different countries, but who all have chosen to write in Italian: choosing Italian is, a conscious and deliberate choice for these writers and it is in the first place, aimed at getting in touch or relating with the exterior, with "the other". These writers write in Italian because they want us to listen to them. Language in this sense becomes a place where to fight, because as Adrienne Rich, reminded her reader" this language smelling of my oppressors that's why I must use in order to speak to them". Why are they transnational writers? Because they experience the paradox of their condition(Sassen,1999): on the one hand the global market tends to eliminate nation states in favour of global economic integration, on the other, there still remain immigration policies based on the oldfashioned conception of nations and borders. 
2- Ornela Vorpsi (Albania), Lilia Bicec (Moldova), Geneviève Makaping (Cameroon), Christina de Caldes Brito (Brazil), Jarmila Ockayová (Slovakia) and finally Jhumpa Lahiri (Bangladesh/USA). They consequently belong to that vast group of writers who have created a new domain within Italian literature. These texts clearly highlight how migration is not just a social or ethnic concept, but an existential condition. Italian literary criticism, dominated by a conservative tendency, has, for many years, removed or even excluded their works, because they did not comply with predetermined literary canons. Thus, texts which have struggled to be accepted as literary works, because long consigned to only be read as records of a social phenomenon.

Defining themselves, on different occasions and for different reasons, "eccentric writers" (far from the centre), is symptomatic of a coincidence between their experiences as narrators and the most stimulating theoretical reflections emerging from feminism. The gaze of these authoresses is the gaze from the margin opening to observe the centre: being outside the centre means, for these women writers, being able to observe and understand the necessary detachment between life and literature, being called upon to operate individual choices that are not dictated by their subscribing to already established models.

Some thematic constants that may be retrieved from their novels: the impact with Italy, the generating disappointment, astonishment and nostalgia; this impact emerges in their fictions from the contrast between near/far, us/you. The theme of metaphoric and literal coldness: coldness indeed characterises a foreign and unwelcoming space, in which to feel disoriented, and which drives the search for a bit of human warmth.

As example of woman writer who belongs to a minor transnationalism we have chosen the Albanian writer Ornela Vorpsi born in Tirana in 1968 when the regime of Enver Hoxha became more and more harsh. She left Albania for political reasons and studied at the Academia di Brera and later in Paris, where she lives now.

Her writing can be defined as "a gift of migration" un [regalo della migrazione], the result of an inspiration strictly correlated to migration (interviewed in Ravenna, 2-12 May 2007). Ornella Vorpsi can be considered an "eccentric writer" in the etymological meaning of being and feeling to be outside the consolidate norm that see the Western world as the centre - both geographical and cultural - as regards the country of origins.

Her eccentricity is born from migration, from her continuous movement from one place to another and the consequent change in her point of view. Migration implies a detachment from the country of origin and the search for a new motherland/ identity/personal balance that in many cases is forbidden.

Now I have become a perfect foreigner. When we become foreigners, we look at the world in a different way from someone who is inside. [...] It is like going to a family dinner with- 
out participating in it; it is as if there is a cold window in between [...] They peer at you, they recognize you, they make you signs so that you can get in and join them, you also see them and reply with the same gestures, but the dinner is over, it is eaten like that. After a while they do not invite you anymore. (The Hand you don't bite [La mano che non mordi] 2007: 19)

[Ormai sono una perfetta straniera. Quando si è così stranieri, si guarda il tutto in modo diverso da uno che fa parte del dentro. [...] È come recarsi a una cena di famiglia e non poter partecipare; si frappone una gelida finestra...: loro ti scrutano , ti riconoscono, ti fanno segni perché tu entri e li raggiunga, pure tu li vedi e rispondi con gli stessi gesti, ma la cena si consuma qui, si consuma così. Dopo poco tempo smettono di invitarti]

The detachment from the motherland permits to look from a critical perspective the country abandoned for political reasons. Through memories and a child's adolescent point of view Ornela Vorpsi remembers in The country where you never die [II paese dove non si muore mai, 2005] the years of her childhood and adolescence in Albania, a sunny but also violent and hard to live in a country dominated by dictatorship's abuses of power. A macho Albania obsessed by sex. To be a woman in a male chauvinist country relegates her to a marginal position: she is not a man and therefore possesses less rights to be free, to live free. But she finds herself in the same position also when she goes abroad and where there is the same repetitive stereotype, which has become almost a rule: the Albanian woman as a prostitute.

The novel Dear children, I write to you [Miei cari Figli, Vi scrivo], that Lilia Bicec published in Italian have the form of letters that Lilia wrote to her children but she never sent to them. Letters she writes to try to find relief from the solitude she feels in Italy, without the children she had to leave behind. In these letters she describes her difficult painful experiences in Italy, when she arrived as an illegal immigrant. Her feeling alien in a country that at first is hostile, since she is there illegally, her difficulty in communicating with others because she cannot speak the language. Lilia is a woman that does not let her be overwhelmed, because she has decided to build another life for herself and her children. This is why, once a job has been found, she starts studying again, teaches herself Italian, and above all, reads in her free time. Distance has enabled her to understand how her relationship with her husband was not funded on mutual esteem and how, in her case, hard work has meant the possibility of reconstructing herself.

Geneviève Makaping from Cameroon has chosen to speak to us in our "own language", from our "own home". She has worked and studied in Italy, has achieved a teaching position within Italian academia, and has written a biographical and anthropological essay Trajectories of gazes. If others were you [Traiettorie di sguardi. $E$ se gli altri foste voi, 2001] where she uses the method of "participating observation", but overturning the usual object of her discipline's gaze, which traditionally alights 
on the "other". Her biographical experience becomes a study on us, the white majority, revealing itself to be lazy and indifferent, when it is not violent and intolerant. While denouncing the injustices suffered, Makaping reveals our own otherness to us. The authoress thus deconstructs the commonplace image of Italians being "good fellas", which has contributed so much to the historical negation and removal of the Italian colonial past in North and Oriental Africa, convincing us we were forever immune from intolerance, racism and xenophobia. Her discursive strategy consists in re-naming everything we ourselves have already branded, labelled and negatively judged: her commitment is aimed at the "deconstruction and re-construction of the meaning of certain concepts”.

\begin{abstract}
Yes, words sometimes are like stones. These words sometimes make me break out in a rash, I was saying, but I strongly resist allowing them to make a dent in my vital organs. What can I do? I deconstruct them. I don't give them another connotation, I limit myself to re-denoting them. [...] For a start... want to be the one to say what my name is. (2009: 31)

[Sì, le parole a volte sono pietre. Tali parole a volte mi fanno venire l'orticaria, dicevo, però rifiuto con forza che intacchino i miei organi vitali. Cosa fare? Le decostruisco. Non do loro un'altra connotazione, mi limito a ri-denotarle. [...] Per iniziare... Voglio essere una che dice che cosa è il mio nome.]
\end{abstract}

Christina de Caldas Brito, Brazilian, offers an example of a hybrid, variegated language in her stories: her heroines speak a language that is a cross between Portuguese and Italian. In Ana de Jesus, as in other stories of her collection Amanda, Olinda, Azzurra e le altre (1998), the reader is struck by the novelty of the linguistic solutions adopted by the writer: her "portulian" (a mix of the two languages), whose rhythms and sounds echo the language spoken by Italian immigrants to Brazil. It is a discursive strategy consisting in the invention of a new expressive code, taking its start from the parody of the "mistakes" typical of foreigners upon first coming into contact with the new language. Although this linguistic game calls for a firm mastery of Italian, the writer tackles it with lighthearted enjoyment, producing that skilful blend of expressive lightness and formal balance that characterise her very personal style.

Slovak writer Jarmila Ockayovà refuses the mother-tongue ideal, since she considers herself a person moving between languages, whose condition of simultaneously belonging and non-belonging allows her to look at identities which have been fixed once and for all and at mother tongues with healthy scepticism, to resist the temptation "to settle in one single conception of sovereign and univocal identity", and to face multiplicity without falling into the trap of relativism. Jarmila Ockayovà uses a culinary metaphor to describe her linguistic position: 
Speaking in one's mother tongue is like finding an already laid table, your food already prepared, brought in from the restaurant kitchen. Adopting a new language, instead, is like having to cook that same dish for oneself. One does the shopping, dirties the kitchen, and notices every single ingredient. Then, upon eating, one is more aware of what's on the table. (1997: 54)

[Parlare la lingua madre é come trovarsi la tavola già apparecchiata, il cibo bell'e pronto che ti portano dalla cucina di un ristorante. Adottare una lingua nuova è invece come doversi cucinare quella stessa pietanza da soli. Fai la spesa, imbratti la cucina, stai attento ad ogni ingrediente. Poi quando mangi, sei più consapevole di quello che hai sul piatto Ockayovà]

On a meta-narrative level, the author's choice of using Italian and the cooking metaphor she uses can be read as a way on incorporating in herself the represented by our language and literary tradition. Language is a privileged means for introspecting "the other" -especially if the writer does not adopts a mother tongue, foreign to her unconscious and to her upbringing: the foreign text then becomes a form of cannibalism, allowing the authoress to establish a distance between the subject of the enunciation and her linguistic expression, accentuating the awareness of its extraneousness and fragmentation. Azade Seyan affirms that the old terms of literary criticism are not adequate to describe a modified reality. Adjectives such as "exilic", "ethnic", "migrant” or "diasporic" are not sufficient to explain the complexity of linguistic processes, the nuances in writing that come out from geographies, stories and cultural practices by women who choose to write in a different language from their "mother tongue". It is thus important to be aware that we do not possess an adequate language for our task and that we are responsible for a reflection and problematization of the terms we use. Azade agrees with what Appadurai states: "No idiom has yet emerged to capture the collective interests of many groups in translocal solidarities, cross-border mobilizations, and post -national identities" (Appaduray 1996).

Thus, the contribution of Italian narrative written by transnational writers consists in the possibility of revealing the deceptive nature of language; in the potential offered by the detachment typical of people living in transit between languages and the ability

to break down a few human and literary stereotypes: because with their works they deconstruct the stereotyped and essentialist image of the "immigrant"; breaking the lim. its imposed on the speaking subjects by the institutions. But above all they remind us that human diversity, with its infinite range of possibilities, is literature's raw material, as well as its reason for being. (EAD, Al di là della parola: 2) 
The second point I would like to analyse is the theme of nostalgia, closely linked to memory and remembrance. These writers' narratives draw from their autobiographical experiences. Indeed the writers pour into the protagonists of their novels and stories their re-worked life material. The fragments of their memories are not represented as if they were simple documents, but they are re-elaborated so as to give a "new version of the old ones", to make us move towards a new way of articulating them. The tension to remember is not just the instrument for a better knowledge of oneself, and of others: it expresses the need to recuperate, recover the past to hand back meaning to the heritage of pain and suffering. In this sense the act of remembering is different from escapist nostalgia (a kind of useless act consisting in wanting something to remain the way it always has been), and it becomes, instead, critical nostalgia, a "deeply subversive political act" for the chance of illuminating and successfully transforming present reality.

Saudade may result in closure and anger when, without substitute gratifications, there prevails in a person the feeling of loss. Yet it may lead to creativity, if it becomes the well whence to draw the deep, fresh waters the colour of the night. Isn't it saudade that drives every writer to transform their thirst into the joy of drinking? Isn't saudade by any chance the foundation of Plato's philosophy, or the energy that drove Dante to Paradise?

[“La saudade può sfociare nella chiusura e nella rabbia quando, senza delle gratificazioni sostitutive, in una persona predomina il sentimento della perdita. Ma può portare alla creatività, se diventa il pozzo dal quale attingere l'acqua fresca e profonda che ha il colore della notte. Non è la saudade che spinge ogni scrittore a trasformare la propria sete in gioia di bere? Non è per caso la saudade il fondamento della filosofia di Platone o l'energia che ha spinto Dante in Paradiso? (de Caldas Brito, Saudade)

As a last example I would like to discuss Jhumpa Lahiri, who could have been considered a hyphenated identity between Bengali language and culture and English, and who now, after having published her latest volume in Italian In Other Words [In altre parole, 2015] winning the Premio Viareggio Versilia Prize and the following year published by Vintage with the title In Other Words - with parallel text in Italian)) can with good reason be considered a transnational writer choosing to write in Italian, a language acquired late in life, driven by her love of and passion for Italian culture and language.

I would like to foreground some points that I feel are very much on the same page as what I have tried to express so far. The es ergo Lahiri picks from Antonio Tabucchi's work is extremely significant because it summarises the entirety of the attitude Lahiri has towards Italian: “... I needed a different language: a language which was a place of love and reflection" [... avevo bisogno di una lingua differente: 
una lingua che fosse un luogo di affetto e di riflessione. Lahiri 2015]. A language she has deeply loved from the very start, a language she fiercely wanted to learn and to which she devoted herself with passion and love for twenty full years. Her book, In altre parole narrates this love at first sight, this enamouring, and the subsequent battles Lahiri engaged to learn Italian. It is a kind of confession, where the writer reveals her motivations, even the existential ones, urging her to write it in Italian, a language she as yet does not speak perfectly, but this very imperfection drives her to attempt writing. Linguistic imperfection "inspires invention, imagination, creativity. It stimulates. The more I feel imperfect, The more I feel alive”, says the writer (Lahiri 2015: II3)

Writing in Italian is a challenge, an ongoing tension for the writer; this difficulty represents a strong creative stimulus for her. The passage from writing in English to Italian reflects, as she herself admits "a radical transition, a state of total bewilderment" [una transizione radicale, uno stato dismarrimento totale.] (Lahiri 2015: 52).

A bewilderment that, however, provokes a new origin for the writer: it is as if she rediscovered for the first time, as she states, the "reasons why I do write, the joy together with the necessity [of writing]" (idem:52). Writing in a foreign language has meant for her to reconstruct her own identity through an act of "transmigration from English into Italian”.

Her dominant language is English, which she had to learn in school, and which then became the language of her novels. We were discussing the previous writers being marginal, in Lahiri's case even the position whence she writes is marginal

I write on the margins, and thus I have always been living on the margins of countries, of cultures. A peripheral area where it is not possible for me to feel rooted, but where by now I feel at ease. The only area I believe in a certain way, I belong to. (...) Since I was a girl I have only belonged to words. I don't possess a definite Country, a definite culture. If I didn't write, if I didn't hammer away at words, I wouldn't feel present on earth. (idem: 75) [Scrivo ai margini, cosi vivo da sempre ai margini dei Paesi, delle culture. Una zona periferica in cui non è possibile che io mi senta radicata, ma dove ormai mi trovo a mio agio. L'unica zona a cui credo, in qualche modo di appartenere. (...) Fin da ragazza appartengo soltanto alla parole. Non ho un Paese, una cultura precisa. Se non scrivessi, se non lavorassi alle parole, non mi sentirei presente sulla terra]

The writer feels as if she were "suspended" between several worlds, and cultures, with an imprecise identity and to describe her situation she resorts to the image of two-faced Janus.

Two faced Janus springs to mind. Two faces looking at past and future at the same time. The ancient god of the threshold, of beginnings and ends. He represents the moments of transition. He watches over gates, over doors. An exclusively Roman god, protecting the 
city. A singular image l'm about to meet everywhere. c

[Mi viene in mente Giano bifronte. Due volti che guardano allo stesso tempo il passato e il futuro. L'antico dio della soglia, degli inizi e delle fini. Rappresenta i momenti di transizione. Veglia sui cancelli, sulle porte. Un dio solo romano, che protegge la città. Un’immagine singolare che sto per incontrare dovunque]

Jhumpa Lahiri interweaves her declarations of love to Italian language and culture with her own life: she juxtaposes her mother, a mother with whom she had a complex relationship, a mother characterised by a monolithic identity, who wouldn't change, obsessively faithful to the culture of her homeland, with her own constant striving to transform and change. This is the reason Lahiri has always deeply loved Ovid's Metamorphoses, which she read when still at University. The passage describing Daphne's flight from Apollo and her metamorphosis in a laurel tree becomes emblematic to explain what writing in Italian has meant for her: "those moments of transition, when something transmutes, constitute the [true] backbone of us all" [quei momenti di transizione, in cui qualcosa si tramuta, costituiscono la spina dorsale di tutti noi] (Lahiri 2015: 125). Lahiri with her work in English and in Italian embodies the figure of a writer/translator/self-translator juggling between languages and cultures, divided selves, multiple voices and identities which as, she says, can 'illuminate' the world.

In conclusion we could hypothesize that writing in a foreign language means to reconstruct one's identity through the "transmigration" from one language/culture to another. Cultural transnationalism does not mean to erase one's roots of belonging but it is rather based on the ides that through the passage in more cultures one's identity can be strengthened and acquire a critical perspective for building up a new future. 


\section{Notes}

* Vita Fortunati was Professor of English Literature at the University of Bologna. She has directed for many years The Interdepartimental Center on Utopian Studies in Bologna. Her main area of research are Modernism, utopian literature, women's writing, cultural memory, nostalgia, the representation of female body, aging between culture and medicine. Her most recent publications are: "The Rhetoric of Thomas More's Utopia: a Key to grasp its Political Message”, Utopia: 500 years, ed. by Pablo Guerra, Ediciones Universidad Cooperativa de Columbia, Bogotá Columbia, 20ı6. "Mort” in Dictionnaire critique de l'utopie aux temps des Lumières, sous la direction de B. Baczko, M. Porret et F. Rosset, Geneve, Georg Editeur, 2016. A. Huxley, Una società ecologica e pacifista, Milano Jaca Book, 20ı1. Federici, Eleonora and Fortunati, Vita, “Theorizing Women’s Translational Literatures: Shaping New Female Identities in Europe through Writing and Translation”, in Times of Mobility, ed.by J.Lukic, and S.Forrester with B.Farag. Ceu Press, 2019, 47-78.

' This paper is a revisioned version of a paper published in 2019: Federici, Eleonora and Fortunati, Vita (2019), “Theorizing Womens's Translational Literatures: Shaping New Female Identities in Europe through Writing and Translation”, in Times of Mobility, ed.by J. Lukic, and S.Forrester with B. Faragó. Ceu Press, 47-78.

${ }^{2}$ Fortunati, Vita, "Cosmopolitanism as a New Perspective in an updated Journey to Utopia” in Travel and Cosmopolitanism from the Island to the World, in Proceedings Madeira Conference (2019), Forthcoming.

${ }^{3}$ See on this topic Sandra Ponzanesi - an expert in Italian Colonial History - Sandra Ponzanesi and Daniela Merolla (eds.), Migrant Cartographies. New Cultural and Literary Spaces in Postcolonial Europe. Lanham, MD, Lexington books, 2005, Daniele Comberiati, “Lo studio della Letteratura italiana della migrazione in Italia e all'estero in una panoramica critica e metodologica" in Modernità letteraria, 8-2015, 43-52; Scrivere tra le lingue. Migrazione, bilinguismo e poetiche della frontiera nell'Italia contemporanea, a cura di DanieleComberiati e F. Pisanelli, 2017.

\section{Works Cited}

Appadurai, Arjan (1996), Modernity at large: Cultural Dimension of Globalization. Minneapolis, University of Minnesota Press.

Benvenuti, Giuliana /Ceserani Remo(2012), La letteratura nell'era globale. Bologna, Il Mulino.

Bicec, Lilia (2013), Miei cari figli, vi scrivo. Torino, Einaudi. 
Comberiati, Daniele (8-2015), “Lo studio della Letteratura italiana della migrazione in Italia e all'estero in una panoramica critica e metodologica”, in Modernità letteraria, 43-52.

De Caldas Brito, Christiana (2004), Amanda, Olinda, Azzurra e le altre. Oèdipus editore.

Federici, Eleonora and Fortunati, Vita (2019), “Theorizing Women's Translational Literatures: Shaping New Female Identities in Europe through Writing and Translation”, in Times of Mobility, ed.by J. Lukic,and S. Forrester with B. Faragó. Ceu Press, 47-78.

Fortunati, Vita (2019), “Cosmopolitanism as a New Perspective in an updated Journey to Utopia in Travel and Cosmopolitanism from the Island to the World" in Proceedings Madeira Conference, Forthcoming.

Kwame, Antony Appiah (2007), Cosmopolitanism: Ethics in a World of Strangers. Penguin Books,London.

Lahiri,Jhumpa (2016), In Altre Parole. Parma, Guanda.

Levinas Emmanuel (1969), Totality and Infinity an Essay on Exteriority (196I). Trans. by Alphonse Lingi, Pittsburgh, Duquesne University Press.

Lionnet Françoise and Shu-mei-Shih (2005),"Introduction” in Minor Transnationalism. Durham and London, Duke University Press

Makaping, Genèvieve (200I), Traiettorie di sguardi. $\varepsilon$ se gli altri foste voi, Soveria Mannelli, Rubbettino Editore.

Ockayová, Jarmila (1997), L'Essenziale é invisibile agli occhi, Milano, Dalai Editore.

Ponzanesi, Sandra and Merolla Daniela (eds.) (2005), Migrant Cartographies. New

Cultural and Literary Spaces in Postcolonial Europe. Lanham, MD, Lexington books.

Robinson, William (13.4 1998), "Beyond Nation-State Paradigms: Globalization, Sociology, and the Challenge of Transnational Studies" in Sociological Forum: 565.

Scrivere tra le lingue. Migrazione, bilinguismo e poetiche della frontiera nell'Italia contemporanea, a cura di Daniele Comberiati e F. Pisanelli, 2017.

Sassen, Saskia (2007), The Sociology of Globalization, New York: W.W. Norton

Seyan,Azade (2001), Writing Outside the Nation, Princeton, Princeton University Press.

Sanford, Susan Friedman (2011), "Towards a Trasitional Turni in Narrative Theory Literary Narratives, Travelling Tropes and the case of Virginia Woolf and the Tagores”, Narrative 19(I)1.32.

Vorpsi, Ornela (2005), Il paese dove non si muore mai, Torino, Einaudi.

-- (2007), La mano che non mordi, Torino, Einaudi. 